\title{
EXPO MILANO 2015
}

\section{CONCEPTUAL MASTERPLAN}

\section{Herzog \& de Meuron}

\author{
Milán, Italia \\ Proyecto, 2009 \\ 0
}

International exhibitions have become actual fairs of architectural prowess where the consistency of the whole ends up subjected to individual vanity. As a critique to this usual approach, in this proposal for the Expo Milano 2015 Herzog \& de Meuron ask, what if instead of exhibiting pavilions each country presents a piece of their land and agricultural landscape? Maybe we would start to speak of 'lands' instead of 'countries', since the original meaning of Milan was precisely 'middle land'.

KEYWORDS · exhibition, land, soil, landscape, Milano

Expo Milan 2015 adorns itself with a proud title: "Feeding the Planet, Energy for Life". What can architecture and urbanism contribute to a World Exhibition? And more specifically: how can the masterplan for a World Exhibition contribute to justify such a proud title? These were the questions we raised when we were asked by the then Mayor of Milan, Mrs. Letizia Moratti, to design the masterplan for the Expo Milano 2015. We never liked such big shows, made to attract and impress millions of visitors. We decided to only accept the invitation to design the Milan masterplan if the client would accept a radically new vision for a World Exhibition, abandoning the obsolete idea of expositions solely based on architectural monuments and outmoded vanity shows of national pride that expos have always been since the mid- $19^{\text {th }}$ century and that we last experienced in the 2010 Shanghai Expo with its overblown, massive structures. We felt encouraged to go for a radical new approach after learning about Carlo Petrini's involvement. In the early days of the process Carlo gave a very impressive speech about his 'Terra Madre' movement in all parts of this planet. The World Exhibition should bring to the fore all the beauty of this planet's agricultural landscapes, but also all the challenges that come with overpopulation, drought, fertilization/industrialization and patent issues for seeds by multinational agro companies. 


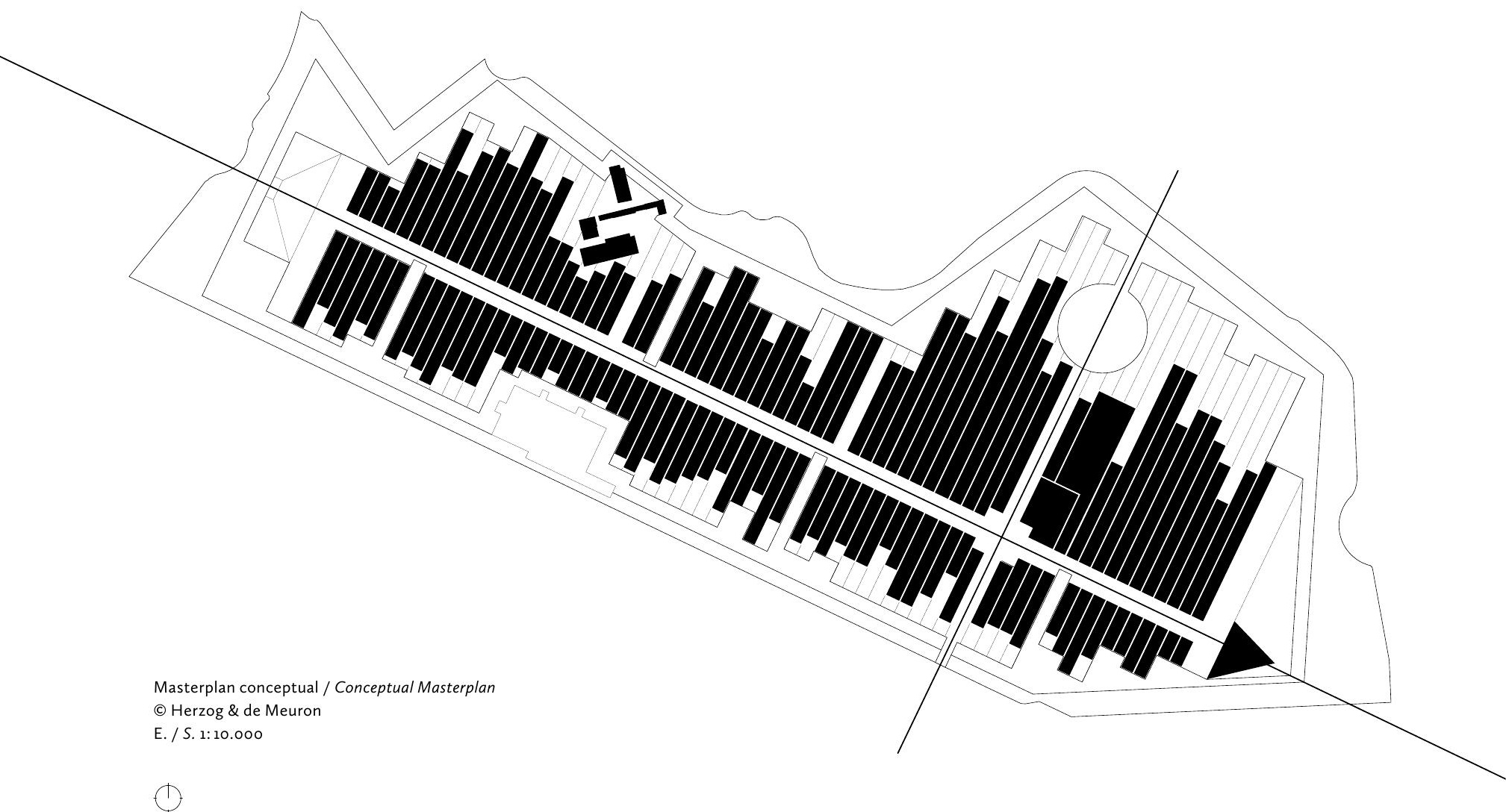

Masterplan conceptual / Conceptual Masterplan c Herzog \& de Meuron

(1)
Masterplan conceptual / Conceptual Masterplan (c) Herzog \& de Meuron
Arquitectos / Architects

Herzog \& de Meuron. Jacques Herzog,

Pierre de Meuron

Arquitecto a cargo / Partner in charge Andreas Fries

Equipo de proyecto / Project team

Lisa Euler, Caetano de Bragança,

María Ángeles Lerín Ruesca, Monica Leung

Ubicación / Location

Rho-Pero, Milán, Italia

Cliente / Client

Expo 2015 S.p.A.

Superficie proyectada / Projected area $315.000 \mathrm{~m}^{2}$

Superficie terreno / Site surface

$$
1.100 .000 \mathrm{~m}^{2}
$$

Año de proyecto / Project year

$$
\text { 2009-2015 }
$$

Ingeniería en Sostenibilidad, Construcción,

Materiales, Infraestructuras y Flujos /

Engineering Sustainability, Construction, Materials, Infrastructures and Flows

William McDonough + Partners,

$$
\text { Charlottesville, usA }
$$

Comité Asesor de Arquitectura /

Architecture Advisory Board

Herzog \& de Meuron, Ricky Burdett, Stefano Boeri

Architetti, William McDonough + Partners

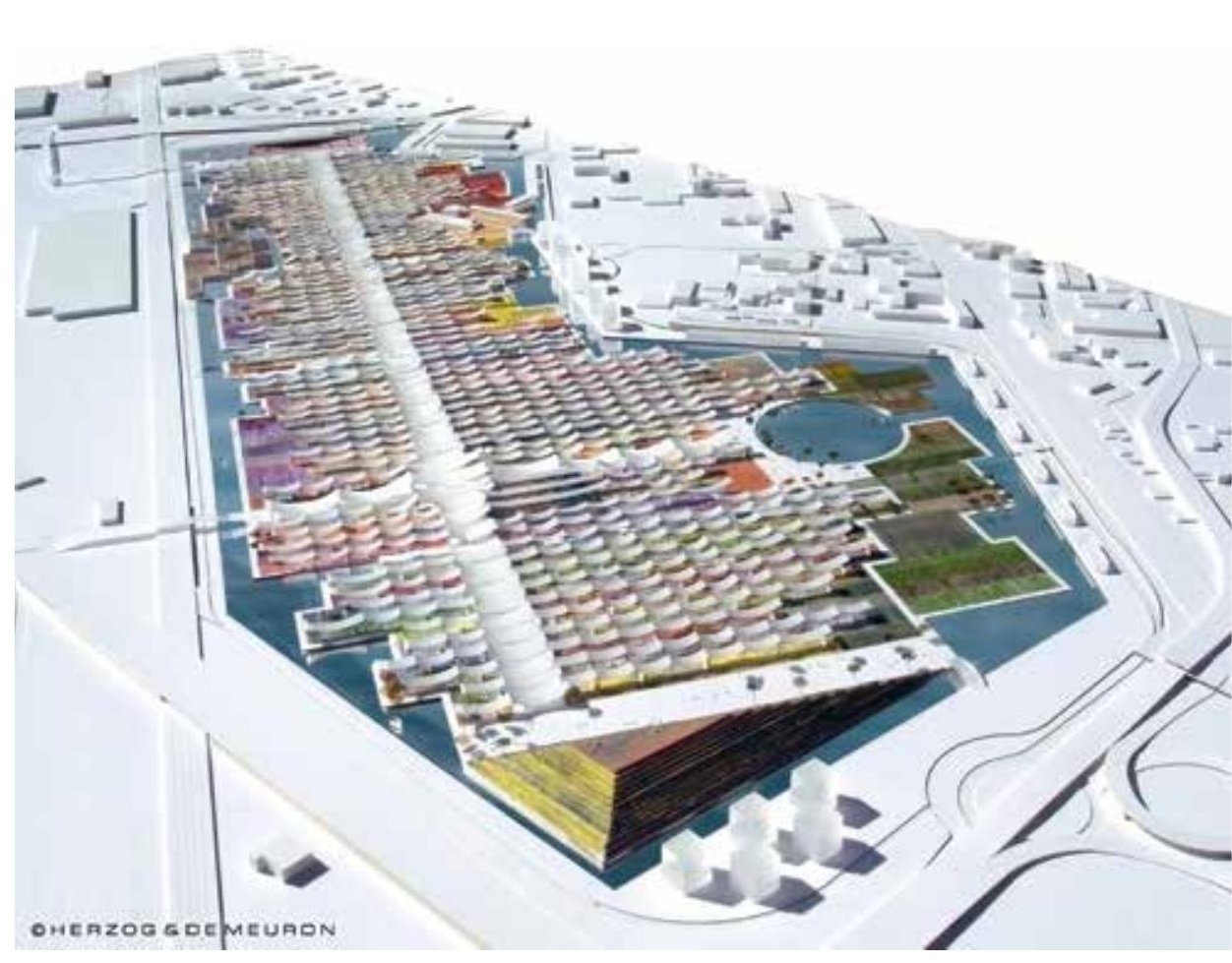




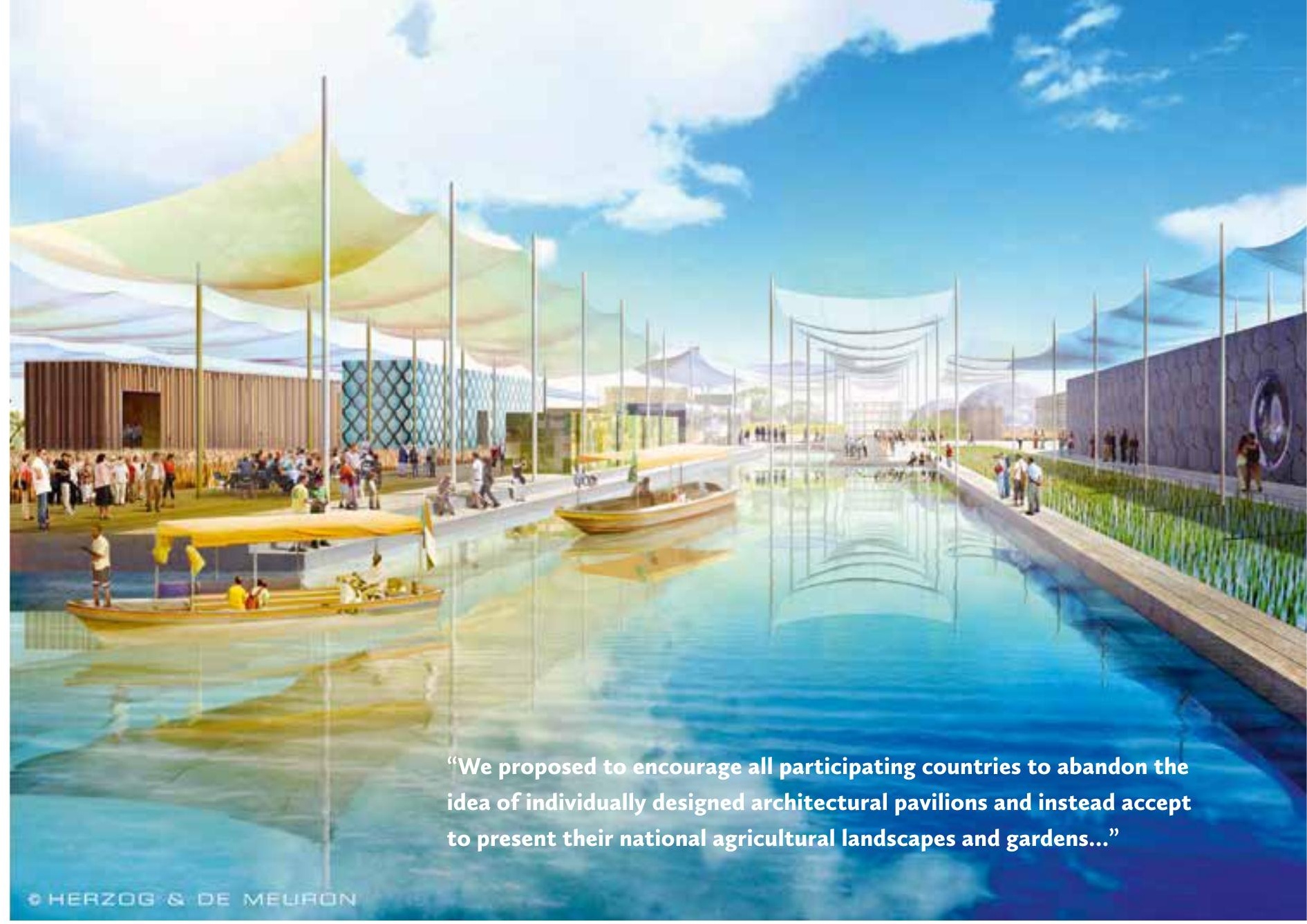

nations, would become a huge, planetary garden with a long table stretching the full length of the boulevard. This table, inspired by Leonardo's 'Last Supper' would become a place for events, for people to meet and come together, symbolically representing a planetary table for all participants. ARQ

\section{HERZOG \& DE MEURON}

<communications@herzogdemeuron.com>

Jacques Herzog and Pierre de Meuron established their office in Basel in 1978. The practice has grown over the years becoming a partnership led by five Senior Partners: Jacques Herzog, Pierre de Meuron, Christine Binswanger, Ascan Mergenthaler and Stefan Marbach. An international team of 40 Associates and about 380 collaborators is working on projects across Europe, the Americas and Asia. The firm's main office is in Basel with additional offices in Hamburg, London, Madrid, New York City and Hong Kong. The practice has been awarded numerous prizes including The Pritzker Prize (USA) in 2001, the RIBA Royal Gold Medal (UK) and the Praemium Imperiale (Japan), both in 2007. In 2014, Herzog \& de Meuron were awarded the Mies Crown Hall Americas Prize (MCHAP) for 1111 Lincoln Road, Miami Beach. 